\title{
Aplikasi Berbagai Jenis Plant Growth Promoting Rhizobacteria (PGPR) dalam Meningkatkan Pertumbuhan dan Hasil Cabai Merah (Capsicum annuum L.)
}

\author{
${ }^{* 1}$ Budiyati Ichwan, ${ }^{1}$ Trias Novita, ${ }^{1}$ Eliyanti dan ${ }^{2}$ Ella Masita \\ ${ }^{1}$ Jurusan Agroekoteknologi Fakultas Pertanian, Universitas Jambi \\ ${ }^{2}$ Alumni Jurusan Agroekoteknologi Fakultas Pertanian Universitas Jambi \\ Jl. Raya Jambi - Ma. Bulian Km 15 Kampus Pinang Masak, Mendalo Darat Jambi 36361 \\ *1 email korespondensi : budiyati_ichwan@unja.ac.id
}

\begin{abstract}
This study aims to examine the effect of PGPR in increasing the growth and yield of red chilies, and to find the type of PGPR that gives the best growth and yield in red chilies.The research was conducted at the Teaching and Research Farm, Faculty of Agriculture, Jambi University, $35 \mathrm{~m}$ above sea level. The study used a randomized block design with one factor, namely various types of PGPR: without PGPR; PGPRI (containing Trichoderma sp., Bacillus sp., Pseudomonas sp., 11 essential macro and microelements, as well as natural amino acids); PGPR 2 (containing Pseudomonas fluorescent, Trichoderma sp., Aspergillus niger, Azobacter sp., Azospirilium sp., And Rhizobium sp.); PGPR 3 (containing Trichoderma sp., Pseudomonas sp., And Rhizobium sp.); and PGPR 4 (containing Azosbacteria sp, Aspergillus niger, and Trichoderma harzianum). Each treatment was repeated five times.The results showed that the application of PGPR was able to increase plant growth and yield of red chilies in the form of plant height (2.12\% - 9.69\%), the total number of branches $(5.25 \%-54.97 \%)$, number of fruits $(13,55 \%-51.40 \%)$ and fruit weight $(54.19 \%-180.53 \%)$. The quality of crop yields has also improved with the application of PGPR. PGPR which contains Pseudomonas fluorescent, Trichoderma sp, Aspergillus niger, Azobacter sp, Azospirilium sp, and Rhizobium sp. is PGPR that provides the best growth and yield of red chilies.
\end{abstract}

Keywords : bacteria, chili, growth and yield,

\begin{abstract}
Abstrak.Penelitian ini bertujuan untuk mengkaji pengaruh PGPR dalam meningkatkan pertumbuhan dan hasil cabai merah dan mendapatkan jenis PGPR yang memberikan pertumbuhan dan hasil terbaik pada cabai merah. Penelitian dilaksanakan di Teaching and Research Farm, Fakultas Pertanian Universitas Jambi, $35 \mathrm{~m}$ di atas permukaan laut. Penelitian menggunakan Rancangan Acak Kelompok dengan satu faktor yaitu berbagai jenis PGPR yang terdiri dari : tanpa PGPR; PGPR1 (mengandung Trichoderma sp., Bacillus sp., Pseudomonas sp., 11 unsur makro dan mikro essential, serta asam amino alami); PGPR 2 (mengandung Pseudomonas fluorescent, Trichoderma sp., Aspergillus niger, Azobacter sp., Azospirilium sp., dan Rhizobium sp.); PGPR 3 (mengandung Trichoderma sp., Pseudomonas sp., dan Rhizobium sp.); dan PGPR 4 (mengandung Azosbakteria $s p$, Aspergillus niger, dan Trichoderma harzianum). Setiap perlakuan diulang lima kali. Hasil penelitian menunjukkan bahwa pemberian PGPR mampu meningkatkan pertumbuhan tanaman dan hasil cabai merah dalam bentuk tinggi tanaman $(2,12 \%$ 9,69\%), jumlah cabang total tanaman (5,25\%-54,97\%), jumlah buah (13,55\%-51,40\%) dan bobot buah (54,19\%-180,53\%). Kualitas hasil tanaman juga meningkat dengan pemberian PGPR. Plant Growth Promoting Rihizobacteria yang mengandung bakteri Pseudomonas fluorescent, Trichoderma sp, Aspergillus niger, Azobacter sp, Azospirilium sp, dan Rhizobium sp) merupakan PGPR yang memberikan pertumbuhan dan hasil cabai merah terbaik.
\end{abstract}

Kata kunci : bakteria, cabai merah, hasil, pertumbuhan

\section{PENDAHULUAN}

Cabai merah (Capsicum annuum L.) merupakan salah satu tanaman hortikultura sayuran di Indonesia yang mempunyai nilai ekonomi tinggi. Cabai merah termasuk kedalam kelompok sayuran unggulan nasional yang menjadi perhatian pemerintah Indonesia saat ini, karena sayuran ini menjadi salah satu penentu tingkat inflasi di Indonesia. Kebutuhan cabai merah akhir-akhir ini semakin meningkat, namun tidak diimbangi dengan peningkatan produksi.

Produktivitas cabai merah nasional saat ini cukup tinggi bila dibandingkan dengan tahun-tahun sebelumnya yaitu sebesar 9,10 ton per hektar (Kementerian Pertanian, 2020). Namun produksi ini jauh lebih rendah bila dibandingkan dengan potensi hasil cabai merah yang dapat mencapai $15-20$ ton ha ${ }^{-1}$. Oleh sebab itu dalam upaya meningkatkan produksi dan produktivitas cabai merah dapat dilakukan melalui perbaikan budidaya cabai merah dan perluasan areal penanaman dengan memanfaatkan lahan kering yang ketersediaannya cukup luas. Hal ini dapat dilakukan dengan memanfaatkan Plant Growth Promoting Rhizobacteria.Penggunaan bakteri pemacu pertumbuhan atau PGPR merupakan salah satu upaya yang dapat dilakukan, selain dapat meningkatkan pertumbuhan dan hasil tanaman PGPR juga dapat meningkatkan kemampuan tanaman cabai merah bertahan terhadap kekeringan, terutama bila pengusahaannya dilakukan di lahan kering.

Plant Growth Promoting Rhizobacteria adalah bakteri tanah yang hidup di sekitar atau pada permukaan akar dan secara langsung atau atau tidak langsung mendorong pertumbuhan dan perkembangan tanaman melalui produksi 
dan sekresi berbagai bahan kimia pengatur di sekitar rhizosfer (Ahemad dan Kilbert, 2013). Pemberian PGPR ke dalam tanah menurut Gupta et al. (2015 )dapat meningkatkan kesuburan tanah, mendorong pertumbuhan tanaman dan menekan fitopatogen.

Hasil penelitian yang dilakukan oleh Moustaine et al. (2017) menunjukkan bahwa berbagai strain bakteri PGPR yang diinokulasikan pada tanaman tomat mampu meningkatkan pertumbuhan akar, meningkatkan diameter batang dan klorofil total. Selain itu adanya peningkatan aktivitas fiksasi nitrogen, aktivitas enzim anti mikroba (selulase, kitinase dan protease), dan peningkatan produksi IAA mengakibatkan peningkatan pertumbuhan dan hasil pada tomat.

Jumlah buah dan bobot buah tanaman terung yang diberi PGPR $30 \mathrm{mlL}^{-1}$ dan kompos kotoran kelinci 10 ton $\mathrm{ha}^{-1}$ lebih tinggi bila dibandingkan dengan perlakuan lainnya (Rohmawati et al., 2017) Sementara itu hasil penelitian Rosyida dan Nugroho (2017) pada tanaman pakcoy menunjukkan bahwa berat segar pakcoy tertinggi didapat dengan pemberian NPK 25\% (12,5 g per lubang tanam) + PGPR 75\% (37,5 g per lubang tanam).

Berbagai PGPR yang beredar di pasaran mengandung mikroorganisme yang berbeda-beda, sehingga efektivitas setiap PGPR juga berbeda-beda tergantung dari mikroorganisme yang dikandungnya dan tanamannya. Oleh sebab itu penelitian ini bertujuan untuk mengkaji peran PGPR dalam meningkatkan pertumbuhan dan hasil cabai merah, dan mendapatkan jenis PGPR yang memberikan pertumbuhan dan hasil cabai merah terbaik.

\section{METODE PENELITIAN}

Percobaan dilakukan di Teaching and Research Farm Fakultas Pertanian Universitas Jambi dengan ketinggian tempat $35 \mathrm{~m}$ dpl. Penelitian menggunakan Rancangan Acak Kelompok dengan lima ulangan. Perlakuan yang dicobakan merupakan berbagai jenis PGPR "komersial" yaitu : tanpa PGPR; PGPR1 (mengandung Trichoderma sp., Bacillus sp., Pseudomonas sp., 11 unsur makro dan mikro essential, serta asam aminoalami); PGPR2 (mengandung Pseudomonas fluorescent, Trichoderma sp., Aspergillus niger, Azobacter sp., Azospirilium sp., dan Rhizobium sp.); PGPR3 (mengandung Trichoderma sp., Pseudomonas sp., dan Rhizobium sp.); dan PGPR4 (mengandung Azosbakteria sp, Aspergillus niger, danTrichoderma harzianum).

Benih cabai merah disemai di media semai, setelah bibit berumur 10 hari dipindahkan ke pembibitan dan dipelihara di pembibitan selama 21 hari, kemudian bibit ditanam di polybag yang berukuran $25 \mathrm{~cm}$ x $40 \mathrm{~cm}$ dengan berat media $10 \mathrm{~kg}$ per polybag. Media untuk pesemaian, pembibitan dan penanaman merupakan campuran tanah : pasir dan pupuk kandang dengan perbandingan $2: 1: 1$. Pemeliharaan tanaman disesuaikan dengan standar budidaya cabai merah di polybag.

Pemberian PGPR dilakukan pada saat tanaman berumur dua minggu setelah tanam (MST), dengan cara disiramkan ke media tanam. Konsentrasi PGPR diberikan sesuai dengan konsentrasi anjuran dari berbagai jenis PGPR yaitu: PGPR1 5mLL ${ }^{-1}$; PGPR2 10mLL ${ }^{-1}$; PGPR3 $3 \mathrm{mLL}^{-1}$; dan PGPR4 $5 \mathrm{mLL}^{-1}$. Volume PGPR yang diberikan sebanyak $100 \mathrm{~mL}$ per tanaman. PGPR diberikan sampai cabai merah berumur 14 MST.

Pemupukan susulan dilakukan dengan memberikan pupuk NPK Mutiara 16:16:16 dengan 1/2 dosis anjuran (0,42 g per tanaman).Pupuk diberikan pada saat tanaman berumur 12 Hari Setelah Tanam (HST), 32 HST dan 42 HST, dengan cara ditugal di sekitar akar tanaman.

Pengamatan dilakukan terhadap tinggi tanaman, jumlah cabang total, jumlah buah, bobot buah, bobot per buah, diameter buah dan panjang buah.Pengamatan dilakukan pada saat panen terakhir periode pembungaan pertama (15 MST).Data dianalisis menggunakan analisis ragam, kemudian dilanjutkan dengan uji Duncan New Multiple RangeTest dengan $\alpha=5 \%$.

\section{Hasil penelitian}

\section{HASIL DAN PEMBAHASAN}

\section{Pengaruh PGPR Terhadap Pertumbuhan Tanaman}

Hasil penelitian menunjukkan bahwa berbagai jenis PGPR berpengaruh nyata terhadap pertumbuhan tanaman cabai merah dalam bentuk tinggi tanaman dan jumlah cabang tanaman.Pemberian berbagai jenis PGPR dibandingkan dengan tanpa PGPR meningkatkan tinggi tanaman cabai merah, dan peningkatan tinggi cabai merah terbesar terdapat pada PGPR 1 dan terkecil terdapat PGPR 4. Untuk jumlah cabang, peningkatan terbesar terdapat pada PGPR 2, sedangkan terkecil terdapat pada PGPR 4 (Tabel 1). 
Budiyati Ichwan, Trias Novita, Eliyanti Eliyanti dan Ella Masita. Aplikasi Berbagai Jenis Plant Growth Promoting Rhizobacteria (PGPR) dalam Meningkatkan Pertumbuhan dan Hasil Cabai Merah (Capsicum annuum L.)

Tabel 1. Peningkatan pertumbuhan cabai merah pada berbagai jenis PGPR dibandingkan dengan tanpa pemberian PGPR

\begin{tabular}{ccc}
\hline Jenis PGPR & \multicolumn{2}{c}{ Peningkatan pertumbuhan $(\%)$} \\
\cline { 2 - 3 } & Tinggi tanaman $(\mathrm{cm})$ & Jumlah cabang total \\
\hline PGPR 1 & 9,69 & 41,77 \\
PGPR 2 & 7,50 & 54,97 \\
PGPR 3 & 6,19 & 43,00 \\
PGPR 4 & 2,12 & 5,25 \\
\hline
\end{tabular}

Dari Tabel 1 dapat dilihat bahwa peningkatan terbesar karena pemberian PGPR terjadi pada variabel jumlah cabang total, sehingga dalam hal ini dapat disimpulkan bahwa jumlah cabang cabai merah merupakan variabel pertumbuhan yang sangat dipengaruhi oleh pemberian PGPR.

Cabai merah yang diberi PGPR menghasilkan tinggi tanaman yang lebih tinggi dibandingkan dengan tanpa pemberian PGPR, namun demikian diantara tanaman yang diberi PGPR, PGPR 1 menghasilkan tinggi tanaman yang paling besar, namun tidak berbeda nyata dengan PGPR 2 (Gambar 1). Tinggi tanaman cabai merah dengan pemberian PGPR 1 sebesar 103,11 cm, sedangkan tinggi tanaman tanpa PGPR sebesar $94 \mathrm{~cm}$.

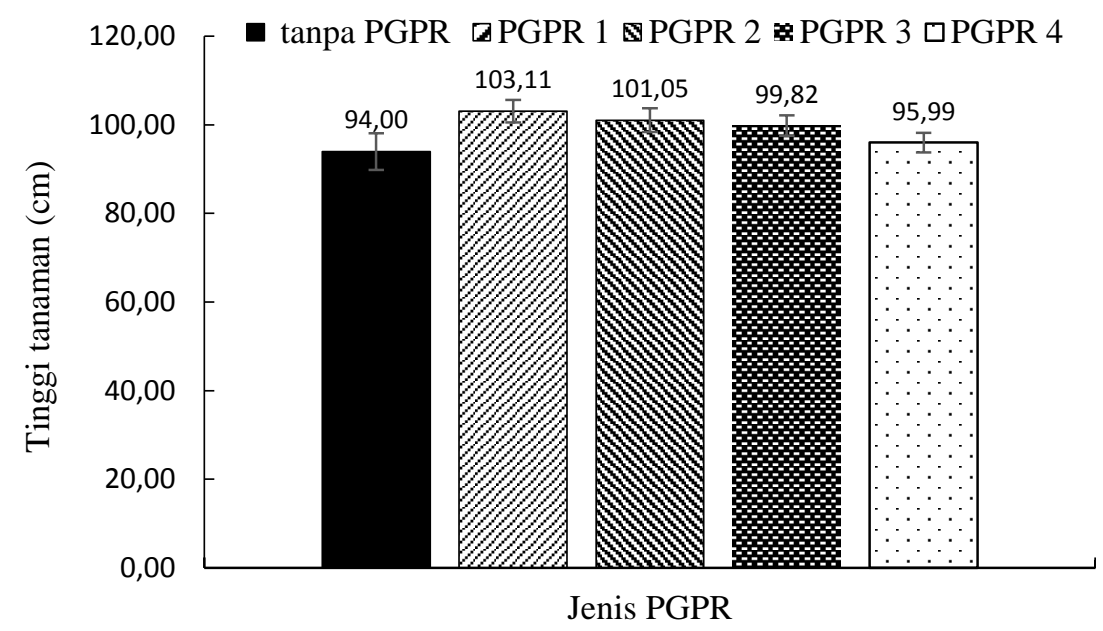

Gambar 1. Tinggi tanaman cabai merah pada berbagai jenis PGPR 15 MST. Error bars menunjukkan standar error $(n=5)$.

Jumlah cabang merah yang diberi PGPR lebih banyak dibandingkan dengan jumlah cabang tanpa pemberian PGPR. Diantara berbagai jenis PGPR yang diberikan, PGPR 2 menghasilkan jumlah cabang total tertinggi $(244,13)$, dan berbeda nyata dengan jenis PGPR lainnya (Gambar 2).

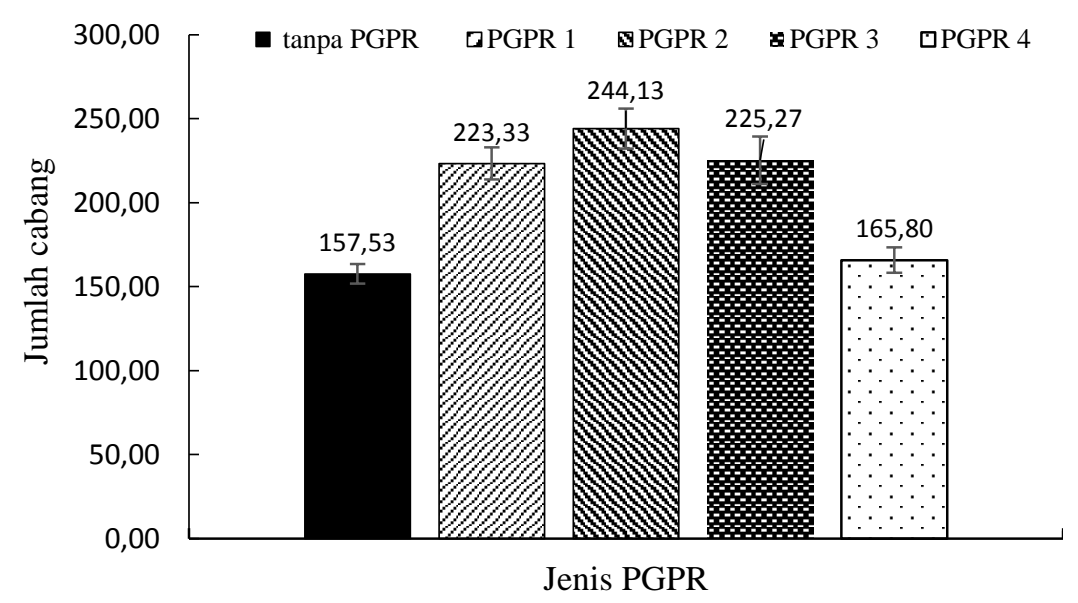

Gambar 2. Jumlah cabang cabai merah pada berbagai jenis PGPR 15 MST. Error bars menunjukkan standar error $(n=5)$. 


\section{Pengaruh PGPR terhadap hasil tanaman}

Hasil tanaman cabai merah dalam bentuk jumlah buah dan bobot buah dipengaruhi secara nyata oleh berbagai jenis PGPR yang diberikan. Pemberian PGPR mampu meningkatkan jumlah buah berkisar 13,55\% sampai $51,40 \%$ bila dibandingkan dengan tanpa PGPR, sementara itu peningkatan bobot buah dengan pemberian berbagai jenis PGPR berkisar antara 54,19\% sampai 180,53\%. Cabai merah yang diberi PGPR 2 mempunyai peningkatan jumlah dan bobot buah tertinggi (Tabel 2).

Tabel 2. Peningkatan hasil cabai merah pada berbagai jenis PGPR dibandingkan dengan tanpa pemberian PGPR.

\begin{tabular}{ccc}
\hline \multirow{2}{*}{ Jenis PGPR } & \multicolumn{2}{c}{ Peningkatan hasil (\%) } \\
\cline { 2 - 3 } & Jumlah buah & Bobot buah \\
\hline PGPR 1 & 34,58 & 116,35 \\
PGPR 2 & 51,40 & 180,53 \\
PGPR 3 & 19,39 & 67,12 \\
PGPR 4 & 13,55 & 54,19 \\
\hline
\end{tabular}

Tabel 2 menunjukkan bahwa berbagai jenis PGPR pada cabai merah meningkatkan jumlah dan bobot buah yang berbeda-beda. Peningkatan bobot buah karena pemberian PGPR lebih besar bila dibandingkan dengan peningkatan jumlah buahnya, namun demikian dapat dilihat bahwa peningkatan jumlah buah pada masing-masing PGPR akan diikuti dengan peningkatan bobot buah. PGPR dengan peningkatan jumlah buah yang kecil akan diikuti dengan peningkatan bobot buah yang kecil, demikian juga bila peningkatan jumlah buah besar, maka peningkatan bobot buahnya juga besar.

Jumlah buah cabai merah yang diberi PGPR lebih tinggi dibandingkan dengan tanpa pemberian PGPR.Diantara berbagai jenis PGPR yang diberikan, PGPR 2 menghasilkan jumlah buah yang paling besar, dan berbeda nyata dengan PGPR lainnya, sementara itu antara PGPR 3 dan PGPR 4 tidak berbeda nyata (Gambar 3). PGPR 4 menghasilkan jumlah buah yang paling rendah dibandingkan dengan PGPR lainnya.

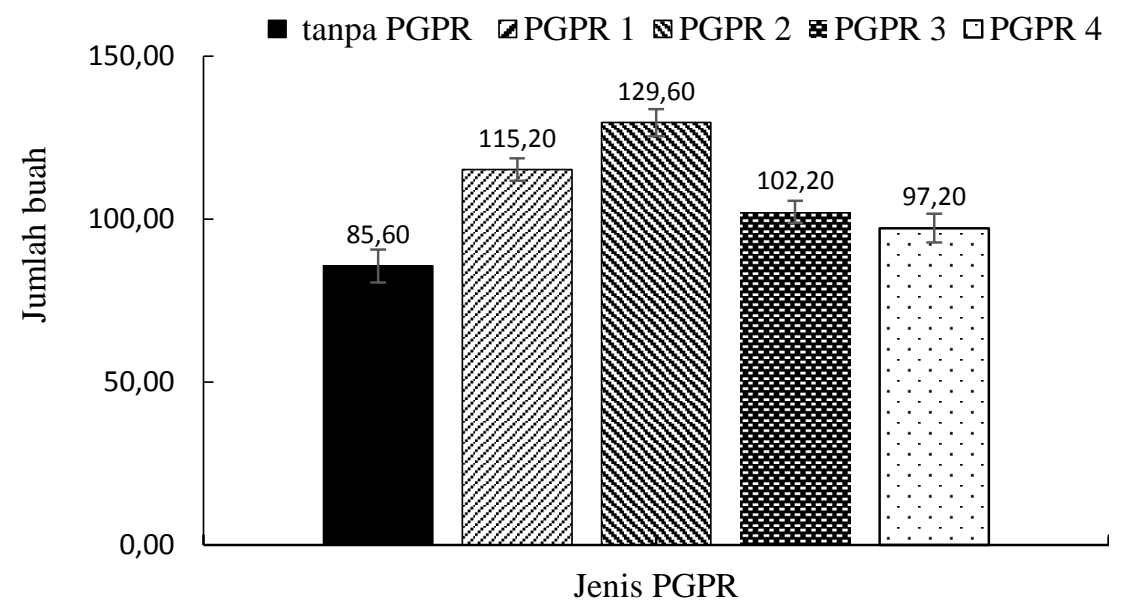

Gambar 3. Jumlah buah tanaman cabai merah pada berbagai jenis PGPR 15 MST. Error bars menunjukkan standar error $(n=5)$.

Bobot buah cabai merah yang dihasilkan dengan pemberian berbagai jenis PGPR sejalan dengan jumlah buahnya. PGPR 2 memberikan bobot buah yang paling tinggi yaitu sebesar 407,22 g, sementara itu bobot buah terrendah dihasilkan oleh tanaman yang tidak diberi PGPR yaitu 145,16 g. PGPR 4 menghasilkan bobot buah yang paling rendah (Gambar 4). 


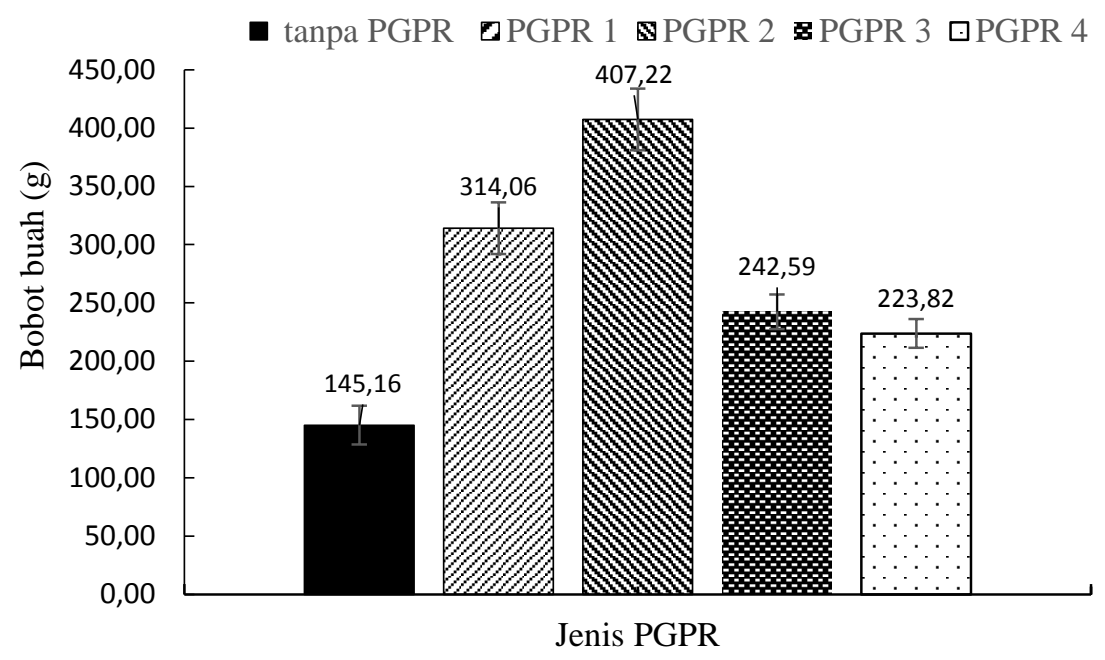

Gambar 4. Bobot buah tanaman cabai merah pada berbagai jenis PGPR 15 MST. Error bars menunjukkan standar error $(n=5)$.

\section{Pengaruh PGPR terhadap kualitas hasil tanaman}

Kualitas cabai merah yang diamati adalah bobot per buah, panjang buah, dan diamater buah. Pemberian PGPR berpengaruh nyata terhadap kualitas buah cabai merah yang dihasilkan. Rata-rata bobot per buah, panjang buah dan diameter buah cabai merah dapat dilihat pada Tabel 3.

Tabel 3. Kualitas hasil cabai merah pada berbagai jenis PGPR

\begin{tabular}{cccc}
\hline Jenis PGPR & Bobot per buah $(\mathrm{g})$ & Panjang buah $(\mathrm{cm})$ & Diamater buah $(\mathrm{cm})$ \\
\hline Tanpa PGPR & $2,15 \mathrm{~d}$ & $12,01 \mathrm{c}$ & $0,66 \mathrm{~b}$ \\
PGPR 1 & $3,64 \mathrm{~b}$ & $13,97 \mathrm{a}$ & $0,90 \mathrm{a}$ \\
PGPR 2 & $4,36 \mathrm{a}$ & $14,12 \mathrm{a}$ & $0,97 \mathrm{a}$ \\
PGPR 3 & $2,72 \mathrm{c}$ & $12,83 \mathrm{~b}$ & $0,76 \mathrm{~b}$ \\
PGPR 4 & $2,58 \mathrm{~cd}$ & $12,54 \mathrm{~b}$ & $0,72 \mathrm{~b}$ \\
\hline
\end{tabular}

Keterangan: Angka-angka yang diikuti huruf yang sama tidak berbeda nyata menurut uji DMRT $\alpha=5 \%$.

\section{Pembahasan}

Hasil penelitian menunjukkan bahwa pemberian PGPR pada tanaman cabai merah mampu meningkatkan pertumbuhan dan hasil tanaman. Tanaman yang diberi PGPR memberikan tinggi tanaman, jumlah cabang total, jumlah buah dan bobot buah yang lebih besar dibandingkan dengan tanaman yang tidak diberi PGPR. Demikian juga dengan kualitas hasil tanaman dalam bentuk bobot per buah, panjang buah, dan diameter buah.

Plant Growth Promoting Rhizobacteria merupakan sekumpulan bakteri yang hidup di sekitar perakaran tanaman. Berbagai jenis bakteri ini dapat menghasilkan hormon tumbuh yang dapat memacu pertumbuhan tanaman. Bakteri Pseudomonas mampu menghasilkan hormon IAA (Shilev, 2013), sedangkan bakteri jenis Azobacter, Bacillus dan Rhizobium mampu menghasilkan hormone sitokin dan giberelin (Kang et al., 2010). Jenis-jenis bakteri ini ditemukan pada berbagai jenis PGPR yang diteliti yaitu PGPR1, PGPR 2, PGPR 3 dan PGPR 4, antara lain Trichoderma, Bacillus, Pseudomonas sp, Aspergillus niger, Azotobacter sp., Azospirilium sp., dan Rhizobium sp.. Peningkatan pertumbuhan dan hasil cabai merah juga disebabkan oleh adanya peran bakteri Rhizobium $s p$. dalam mengikat nitrogen bebas dari udara (Zahran, 2001), sehingga meningkatkan ketersediaan nitrogen bagi tanaman. Bakteri Bacillus sp., Pseudomonas sp., dan Rhizobum sp. juga memainkan peran yang penting dalam meningkatkan ketersediaan P dalam larutan tanah (Zaidi et al., 2009).

Peningkatan pertumbuhan dan hasil cabai merah yang diberi PGPR juga disebabkan meningkatnya kemampuan akar tanaman menyerap air dan hara dari tanah. Peningkatan jumlah dan massa jaringan akar meningkatkan jangkauan akar tanaman untuk penyerapan air dan hara yang memungkinkan akar untuk berkembang di lingkungan yang langka air (Enebe dan Babalola, 2018). Adanya bakteri Pseudomonas sp.yang mampu menghasilkan ACC-deaminase untuk mengurangi tingkat etilen di akar menyebabkan tanaman mampu bertahan terhadap stres lingkungan (Etesami dan Maheswari, 2018). Hasil penelitian Niu et al. (2018) menunjukkan bahwa Pseudomonas fluorescens, Enterobacter hormaechei, dan Pseudomonas migulae mampu menghasilkan EPS (Ekso Poli Sakarida) yang merangsang perkecambahan bibit tanaman millet di bawah cekaman kekeringan. 
Hasil penelitian juga menunjukkan bahwa diantara PGPR yang diperlakukan, PGPR 2 memberikan pertumbuhan dan hasil cabai merah yang lebih baik dibandingkan dengan jenis PGPR lainnya. PGPR 2 merupakan jenis PGPR yang mengandung jenis bakteri yang paling lengkap yaitu 6 jenis bakteri dibandingkan dengan jenis PGPR lainnya yang hanya mengandung 3 jenis bakteri. Diantara bakteri yang dikandung oleh PGPR, ada satu bakteri yang tidak dimiliki oleh PGPR lainnya yaitu Azospirillum sp.

Azospirillum sp. merupakan bakteri yang dikelompokkan kedalam ePGPR yaitu bakteri yang hidup di rhizosfer, di rhizoplane atau di ruang antar sel-sel korteks (Ahemad dan Kilbert, 2014), dan merupakan bakteri non simbion (Bhattacharyya dan Jha, 2012). Adanya bakteri Asozpirillum sp.bersama dengan Rhizobium sp. mengakibatkan meningkatnya pertumbuhan tanaman dan hasil cabai merah yang lebih baik. Hasil penelitian ini sejalan dengan hasil peneltian yang dilakukan oleh Molla et al. (2001) dan Remans et al. (2008) dimana inokulasi ke dua jenis bakteri ini pada berbagai jenis legume dapat meningkatkan jumlah nodul total, meningkatkan aktivitas acetylene reduksi, dan kandungan $\mathrm{N}$ total, serta hara mikro lainnya dibandingkan dengan bila hanya mengggunakan Rhizobium sp. Diduga dengan adanya bakteri Asozpirillum sp.pada PGPR 2, maka dapat meningkatkan efektivitas kerja dari bakteri lainnya, sehingga mampu berperan positif dalam meningkatkan pertumbuhan dan hasil cabai merah. Bila dilihat dari hasil penelitian, ternyata PGPR 1 memberikan hasil yang lebih baik dibandingkan dengan PGPR 3 dan 4. Hal ini disebabkan PGPR 1 walaupun hanya mengandung tiga jenis bakteri, namun dilengkapi dengan unsur hara makro dan mikro yang dibutuhkan oleh tanaman yanag tidak dimiliki oleh PGPR 3 dan 4.

Hasil penelitian menunjukkan bahwa pemberian berbagai jenis PGPR pada cabai merah mampu meningkatkan tinggi tanaman $(2,12 \%-9,69 \%)$, jumlah cabang $(5,25 \%-54,97 \%)$, jumlah buah $(13,55 \%-51,40 \%)$, dan bobot buah $(54,19 \%$ - 180,53\%) dibandingkan dengan tanpa pemberian PGPR.

\section{KESIMPULAN}

Pemberian berbagai jenis PGPR mampu meningkatkan pertumbuhan cabai merah sebesar 7,37\%-31,24\% dan hasil sebesar 33,87\%-115,97\%. PGPR yang mengandung Pseudomonas fluorescent, Trichoderma sp., Aspergillus niger, Azotobacter sp., Azospirilium sp., dan Rhizobium sp. merupakan PGPR yang mampu memberikan pertumbuhan, hasil dan kualitas hasil cabai merah terbaik.

\section{DAFTAR PUSTAKA}

Ahemad, M., andM. Kilbret. 2014. Mechanisms and applications of plant growth promoting rhizobacteria: Current Perspective. Journal of King Saud University Science (Review), 26: 1- 20.

Bhattacharyya, P.N., and D.K. Jha.2012. Plant growth-promoting rhizobacteria (PGPR): emergence in agriculture. World J. Microbiol Biotechnol, 28: 1327-1350 (12)

Enebe, M.C., and O.O. Babalola. 2018. The influence of plant growth-promoting rhizobacteria in plant tolerance to abiotic stress: A survival strategy. Applied Microbiology and Biotechnology, 102:7821-7835.

Etesami, H., and D.K.Maheshwari. 2018. Use of plant growth promoting rhizobacteria (PGPRs) with multiple plant growth promotion traits in stress agriculture: Action mechanisms and future prospect. Exotoxicology and Environment Safety 156:225-246.

Gupta, G., S.S. Parihar, N.K. Ahirwar, S.K. Snehi, and V. Singh. 2015. Plant growth promoting rhizobacteria (PGPR): current and future prospect for development of sustainable agriculture. Microb Biochem Technol 7(2): 96-102.

Kang B.G., W.T. Kim, H.S. Yun, and S.C. Chang. 2010. Use of plant growth-promoting rhizobacteria to control stress responses of plant roots. Plant Biotechnol Rep, 4: 179-183.

Kementrian Pertanian. 2020. Data lima tahun terakhir. www.pertanian.go.id (diakses 18 Januari 2020).

Moustaine, M., R. Elkahkahi, A. Benbouazza, R. Benkirane,andE.H. Achbani. 2017. Effect of plant growth promoting rhizobacterial (PGPR) inoculation on growth in tomato (Solanum lycopersicum L.) and characterization for direct PGP abilities in MoroccoJournal of Environment, Agriculture and Biotechnology 2(2):590-596.

Molla, A.H., Z.H. Shamsuddin, M.S. Halimi,M. Morziah, and A.B. Puteh. 2001. Potential for enhancement of root growth and nodulation of soyean co-inoculated with Azospirillum and Bradyrhizobium in laboratory systems. Soil Biology \& Biochemistry 33:457-463.

Niu, X., L. Song, Y. Xiao, and W. Ge. 2018. Drought-tolerant plant growth-promotingrhizobacteria associated with foxtail millet in a semi-arid agroecosystem and their potential in alleviating drought stress. Fronties in Microbiology vol.8, article 2580. 
Budiyati Ichwan, Trias Novita, Eliyanti Eliyanti dan Ella Masita. Aplikasi Berbagai Jenis Plant Growth Promoting

Remans, R., L. Ramaekers, S. Schelkens, G. Hernandez, A. Garcia, J.L. Reyes, N. Mendez,V. Toscano,M. Mulling, L. Galvez, and J. Vanderleyde. 2008. Effect of Rhizobium-Azospirillum coinoculation on nitrogenfixation and yield of two contrasting Phaseolus vulgarisL. genotypes cultivated across different environment. Cuba. Plant Soil 312:25-37

Rohmawati, F.A., R. Soelistyono, dan Koesriharti. 2017. The effect of PGPR (Plant Growth Promoting Rhizobacteria) and manures rabbit fertilizer on growth and yield of eggplant (Solanum melongena L.). Jurnal Produksi Tanaman 5(8):1294-1300.

Rosyida, dan A. S. Nugroho. 2017. The effect of NPK fertilizer dose and Plant Growth Promoting Rhizobacteria (PGPR) on fresh weight and leaf chlorophyll content of pakchoy (Brassica rapa L.). Bioma 6(2): 42-56.

Shilev,S. 2013. Soil rhizobacteria regulating the uptake of nutrients and undesirable elements by plants. InN. K. Arora (ed.). Plant Microbe Symbiosis: Fundamentals and Advances (pp149-161). Springer, India.

Zahran, H.H. 2001. Rhizobia from wild legumes: diversity, taxonomy, ecology,nitrogen fixation and biotechnology. J Biotechnol 91: 143-153.

Zaidi, A., M.S. Khan, M. Ahemad, and M. Oves. 2009. Plant growth promotion by phosphate solubilizing bacteria. Acta Microbiol Immunol Hung 56: 263-284. 